\title{
Research into Behaviour Patterns Typical for Consumers of Construction Material as the Mission of Ecological Management
}

\author{
Zinaida Ivanova ${ }^{1, *}$, and Tatiana Smetanina ${ }^{2}$ \\ ${ }^{1}$ Moscow State University of Civil Engineering, 129337 Yaroslavskoye shosse 26, Moscow, Russia \\ ${ }^{2}$ Kozma Minin Nizhny Novgorod State Pedagogical University (Minin University), 603950 \\ Ul'yanova str. 53, Nizhny Novgorod, Russia
}

\begin{abstract}
The objective of the co-authors is to study the motivation of purchasers of construction/finishing materials and the criteria that govern their selection. No systemic studies of consumer behavioral models and stereotypes in respect of residential housing have been performed so far. However, the environmentally determined management techniques, applicable to the production of building materials and construction of residential housing, are highly relevant both worldwide and in the Russian Federation. The co-authors have developed an original research methodology, drafted a questionnaire, and conducted a pilot survey. Its findings have proven that the price and quality of construction materials are the main factors that influence the decision making process in favor of particular items. Mere $14 \%$ of the respondents chose environmental friendliness as the decision making criterion. The findings of the focus group projects have also proven the trustworthiness of the stereotypes and behavioral models identified by the co-authors. The co-authors make a conclusion that further sociological surveys are needed to implement the patterns of environmentally determined management and to influence the value paradigms of the population.
\end{abstract}

\section{Introduction}

An urban resident spends about $90 \%$ of his or her spare time indoors, that is, at work, at home, or inside any public office. We believe that our houses or flats are $100 \%$ per cent safe, although the materials used to build or to renovate them may be dangerous for our health.

All construction and finishing materials may be broken down into ecological and nonecological ones. The latter can do a lot of harm to the human health. Ecological materials include those that comply with the following requirements:

- they contain no irritant or toxic components ;

- they demonstrate minimal natural radioactivity;

- they are recyclable and safely reusable;

* Corresponding author: ivanovazi@mail.ru 
- their production is based on the most advanced technologies that cause minimal damage to the environment [1].

In other words, an environmentally safe house must be made of the materials which do not produce any toxic impact on its residents, on the one hand, and the environment, on the other hand. Therefore, ecological materials include timber, building stone, clay, straw, paper, cotton, bamboo, glass, and aluminum, what are widely used, for example, in the construction of half-timbered buildings [2]. There is no doubt that $100 \%$ ecological materials no longer exist, and any advanced construction and finishing materials contain polymers or chemical components; however, this article covers the issue of their ability to comply with the environmental standards set by the law. Presently, those materials, which are considered conventionally safe, enjoy wider use. They are also made of particular natural resources, and they do no harm to the environment. These materials demonstrate high performance values. As a rule, they include bricks, finishing and roofing tile, aerated concrete.

Today a wide selection of construction materials, some of which fail to comply with the quality standards, is offered on the market. According to the developers of the Ecomaterial project, about fifty per centum of construction materials, offered on the unofficial market, do not comply with the All-Russian State Standards, and they may be a hazard to people and the environment. Their consumers do not have the slightest idea that the purchase of a new flat or the renovation of the old one can bring adverse consequences to their health.

Nowadays, environmentally safe materials are more often used in the process of construction of residential houses in Europe. Economically developed countries of the European Union spend substantial amounts on safe construction materials, used to build residential, office and industrial buildings, as the calculations have proven that these costs will pay off sooner or later. For example, The German builders, using "environmentally unfriendly" materials, have to pay taxes at higher rates than the builders using environmentally safe construction materials.

Having analyzed the German housing market, we have found out that customers tend to buy ecological houses for economic reasons there, as banks issue loans more willingly, if the purchased housing is ecologically safe. Besides, there is a special group of customers who take a particular care of their health, and their share reaches $30 \%$ of the market. The reason for buying green homes consists in the environmental protection and care for personal health. These customers collect detailed information about the flat, its construction and finishing materials, the extent of their harmlessness, and they choose the housing built in compliance with green standards.

German producers of green construction materials also offer their arguments to substantiate their viewpoint. Group one represents "ideologically motivated" producers, and they take care of the environment, while group two represents strong holding companies, which cannot operate in any other way due to their high profiles and market positions.

The EU constituent states practice environmental management, or environmentally determined management of the process of advanced production of construction materials; these countries do their best to make their policies as green as possible.

\section{Literature review}

Numerous recently published problem-oriented articles cover the environmental properties of construction materials. The first group of works deals with the research into the hazardous properties of construction materials. The Russian researchers, engaged in the analysis of impacts produced by construction materials on the environment, include A.S. Tsovrebov, E.G. Velichko, and E.A. Yaily. They study the chemical components of construction products and offer their recommendations in respect of the chemical 
composition, ecological, toxicological, and hygienic properties of construction materials, before the latter enter the market. They also develop their recommendations for consumers in respect of the prevention of any hazardous impacts $[3,4,5]$. The second group of researchers studies the greening of the process of production of construction materials. Several articles cover the greening of the cement industry, which is particularly harmful and dangerous $[6,7]$. The findings of the research projects and new innovative materials are offered in the third group of works $[8,9,10]$. Vladimir Ilyichev, member of the Russian Academy of Architecture and Construction Sciences (RAACS), and his research team, draw a lot of attention to the production and application of environmentally friendly construction materials [11].

However, the overwhelming majority of articles, published in journals and newspapers, and distributed in the Internet, inform readers about the hazardous impact of particular construction materials or products that contain chemicals; thus, these publications act as the advertisements of other materials or products. This is the way producers of construction materials or construction companies compete for the market share for their products or services.

The importance of research into the motivation and behavioral patterns of consumers is acknowledged worldwide. The mission of entrepreneurs and market researchers is to change the behavioral patterns in favour of particular commodities. The business community is primarily governed by its willingness to generate cash; otherwise it will turn uncompetitive in the market. The social responsibility of producers and sellers is a complex issue, which is also influenced by the government policy, consumption preferences of the society, and the market position of producers [12].

We have not identified a single research into the consumer behavior in the market of construction materials and services in Russia. Some projects deal with the study of consumers of products manufactured by particular construction companies [13]. For example, in 2004, a thorough overview of the market of construction materials was made by the consulting department of the INEK Group; versatile groups of consumers and their preferences were the subject of research in this overview [14]. No major research projects of this kind have been implemented since then.

\section{Research Objectives}

What motivates the producers of dangerous construction materials? Why do these companies ignore environmental standards? What motivates the consumers of these commodities? What motivates the Russian buyers who purchase new housing or finishing materials for their flats? The objective of this article is to identify the motivation and the choice criteria.

The relevance of this research project is exceptionally high to the unavailability of any systemic studies of behavioral models and stereotypes in respect of consumers of construction materials. Its relevance is also driven by the unavailability of any methodology for the development of any conscious demand for green housing in Russia.

\section{Methods}

The main data collection methods, employed in the process of research into the motivation of producers and their preferences, include the analysis of secondary documents, polls conducted in the form of questionnaires, in-depth interviews, focus groups, and observations. Each of the above methods is equally valuable for the implementation of the process of environmental management. 
The fundamental work, written by L. Blackwell, in which he analyses micro-cultures and their influence on the consumer behavior, can serve as the methodological basis for the research [15]. Research projects may also rely on the methodology applied by Boston Consulting Group, the international leader in the development of corporate marketing strategies. The title of their research reads as "The global green consumer survey". This poll was conducted in Canada, France, Italy, Japan, the USA, Germany, Spain, and the UK. Nine thousand consumers participated in the poll conducted over the Internet. Besides, consumers were interviewed directly in the seven largest cities of China. Mid-level and senior level employees of over twenty network retail companies were interviewed about their strategies and experience in dealing with green commodities [16].

The co-authors have developed an original methodology and drafted a questionnaire. The pilot sociological survey was conducted in Moscow in April 2016 over Internet.

Besides, the co-authors have conducted two group interviews (focus groups) with the first-year students, majoring in fire safety, and third year students, majoring in architecture at Moscow State University of Civil Engineering (MSUCE).

\section{Results}

The total number of respondents was 100 . The age of the respondents, who participated in the pilot testing of the questionnaire, varied from 18 to 55; therefore, no analysis of the choice reasons was performed.

The project developers believe that their mission is to find out whether the respondents have their flats renovated and what arguments govern their choice of construction and finishing materials.

The respondents gave the following answers to the question "how many times did you have your flat renovated?": never $-19 \%$, once $-23.8 \%$, twice $-14.3 \%$, and more than twice $-42.9 \%$. This means that the respondents had a sufficient experience in renovating their flats and purchasing all the necessary materials. The next question read as follows: "what arguments drive your choice of finishing materials for your flat?" The majority of the respondents believed that the main criteria included the price, the quality, the visual appeal, and the style of their rooms. The environmental friendliness of the materials they bought took the interest of a small share of the respondents, or 14.3\% (Fig. 1).

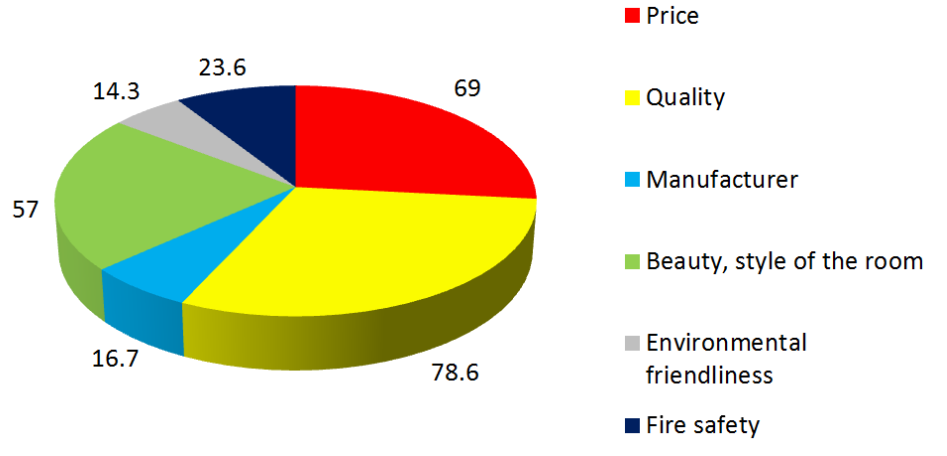

Fig. 1. The arguments of the choice of finishing materials.

One question dealt with the flammability of construction and finishing materials. The respondents turned out to be aware of the flammability properties. They gave the following answers to the question "do you know what materials are fire-proof?": yes - 50\%, no $50 \%$. There was no doubt that the respondents had hardly completed an in-depth study of the fire safety of the materials they bought; however, nonetheless, they had some 
knowledge of the subject matter. For example, they knew that construction materials contained flammable chemicals, including polymers, lacquers and varnishes.

The project developers found out that the respondents asked for the advice of people, engaged in the provision of renovation services and/or in the distribution of construction or renovation materials. Our question read as: "do you ask anybody for advice when buying construction materials?"

The respondents answered that they had addressed their designer $-14.3 \%$, a specialist in this area $-50 \%$, a shop assistant $-42.9 \%$, nobody $-14.3 \%$ (Fig. 2). The majority of the respondents addressed their questions to other people who know something about the renovation.
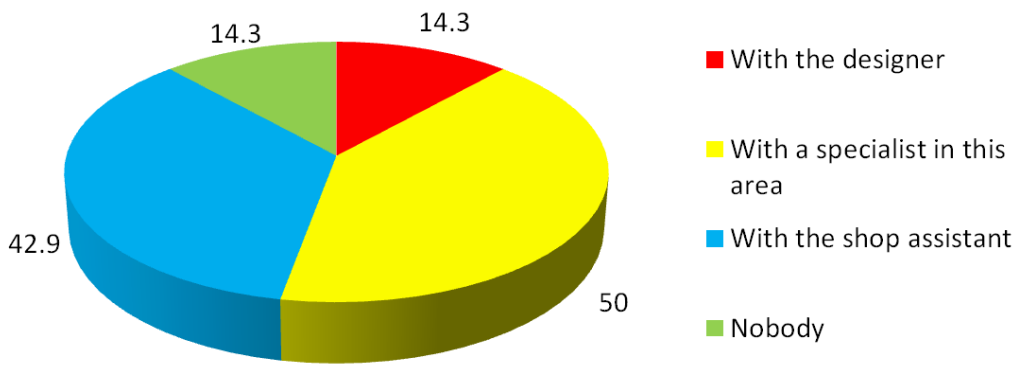

Fig. 2. The respondents asked for the advice of other people, when buying construction materials.

The respondents were asked to complete the following sentence: "The choice of finishing materials is a headache because..." Here are some examples:

1) "I need to find the most perfect material, which must represent a combination of quality, price, practicability, safety, and user friendliness";

2) "the wrong choice may threaten one's health and safety of residents";

3) "it is important to find the proper price to quality and user friendliness ratio";

4)"the choice is extensive, but the knowledge of the subject matter is poor."

Our group interviews identified that the students, majoring in the fire safety, were serious about the environmental safety of the construction or finishing materials they chose. Six out of ten students said that they had studied the environmental properties of materials before buying them, while four students say that their decision to make a purchase had been driven by the price. The future architects preferred the materials that could be used to easily implement their architectural and interior design projects.

\section{Discussion}

So far, the poll findings cannot be considered highly representative, because only a pilot pall has been launched. The objectives of our pilot poll are: 1) to learn more about the state of affairs in the industry, 2) to pilot test the questionnaire in respect of the adequate understanding by the respondents of the questionnaire questions.

Nonetheless, we believe that even this small sampling has helped us to prove our hypotheses:

1. The business community in Russian Federation is only interested in generating profits, while it does not care for the condition of the biosphere or the human health.

2. The purchase of green houses and materials is limited by the financial capacity of the customers, because green houses are very expensive.

Our hypothesis was proven by the answer to the question "what arguments drive your choice of finishing materials for your flat", because the majority of our respondents ignored 
the answer that read as "environmental friendliness" (14.3\%), and believed that the price, the quality, the style were more important. Therefore, we have to admit that we choose cheap products and ignore our health and the health of our relatives. According to Leo Hollis, a British historian and urban specialist, we, the residents, are the main obstacle on the way to the improvement of the environmental friendliness of our cities [17]. However we shouldn't blame our respondents for their answers, as there is no malice in them. Their behavior can be easily explained by the: 1) insufficient environmental education, absence of any elementary knowledge about the environmental friendliness of structures, materials, instruments, and other items around us, the unwillingness of the business community to inform buyers about the true properties of the materials they produce, or the illiteracy of the business community [18] ; 2) the absence of the health culture or the unavailability of the practice of paying attention to the housing safety; 3) the overreliance upon producers; 4) no money to buy ecological finishing materials [19]. Any further development of the environmental sustainability in the construction industry needs to enjoy demand in the society, the business community, and public authorities. Consumers cannot pay extra for a mere "eco-" prefix, that's why they buy the housing which is harmful for their health at agreeable prices [20].

The breakdown of the answers to the question "do you address anybody for advice when buying construction materials?" may also be easily explained by the mentality of Russians. Few respondents address their designers because few of them have enough money to hire a designer. As a rule, the majority of Muscovites design their flats themselves, and their specialists in the field are the members of the team of workers invited to renovate their flats. The customers can hardly rely on their knowledge of the ecological properties of finishing materials; these specialists know more about their quality or durability. Assistants, employed with the stores of construction materials, have some knowledge of the subject matter; however, even if they have been working in this industry for a long time, they have no degrees in this field [21,22]. Their mission is to sell as many commodities as possible to generate as much cash as possible.

The problem is that the government must set the stage for the investments to be made into the manufacturing of green products in the future, for the responsible executives to be encouraged to assure the compliance of their products with the green standards. There is a need to identify or to develop new methods and techniques for the distribution of construction products in the retail market through the target-oriented generation of awareness among the customers and the commodity positioning. Russia should adopt the example of Germany, where the government cuts the tax rates, applied to the producers of green products, and supports their consumers.

\section{Conclusions}

According to the theory, developed by J.N. Sheth, B.L. Newman, and B.L. Gross, consumer behavior is exposed to the influence of a wide range of values, including functional, conventional, social, emotional and epistemic ones [23, 24]. All these values shape up the choice process, as they help buyers to develop the need for the product due to its prestige. Cultural values also influence the behavioral model of Russian buyers; however, Russian buyers don't have environmental friendliness of construction/finishing materials on the list of their values, and this fact's been proven by the findings of the pilot survey and the secondary sources study implemented by the co-authors. We regret to conclude that the state, the producer and the buyer hardly feel the need for "green" construction processes, "green" construction materials or technologies. Only 94 construction facilities are certified according to international green standards BREEAM and LEED in Russia. For comparison, 4,977 construction facilities in Great Britain, 775 in 
France, 684 in UAE, 240 in Germany, and 124 in the Czech Republic have green certificates issued [25]. Representative sampling and mass survey are needed to implement a deeper research into behavioral models in the market. The authors are willing to continue their research in order to develop the framework for the ecologically determined system of management in the construction industry.

\section{References}

1. Information on http://www.vashaibolit.ru/11557-opasnye-dlya-zdorovya-stroitelnyematerialy.html

2. D.S. Gavrikov, S.D. Mezentsev, Vestnik MGSU, 8, 7-17 (2015)

3. E.S. Tskhovrebov, E.G. Velichko,Vop Stroitel'nye materialy, 5, 99-103 (2014)

4. E.S. Tskhovrebov. Vestnik Kostromskogo gosudarstvennogo universiteta im. N.A. Nekrasova, 3, 10-14 (2013)

5. E.S. Tskhovrebov, E.A. Yayli. Obespechenie ekologi cheskoy bezopasnosti pri proektirovanii ob"ektov nedvizhimosti $i$ provedenii stroitel'nykh rabot (Izd-vo RGGMU, Sankt-Peterburg, 2013)

6. M.Ya. Bikbau, V.I. Zharko, Stroitel'nye materialy, oborudovanie, tekhnologii XXI veka, 7-8, 22-25 (2015)

7. B. Kh. Sanzhapov, O.A. Cheremushkin, Biosfernaya sovmestimost': chelovek, region, tekhnologii, 2, 89-95 (2013)

8. X. Liu, X. Z. Gong, Y. Liu, Z. G. Peng, Materials Science Forum, 814, 430-434 (2015)

9. H. N. Abdelhamid, Materials Science Forum, 832, 28-53(2015)

10. R. Spiegel, D. Meadows, Green Building Materials: A Guide to Product Selection and Specification, , 3rd Ed (John Wiley \& Sons, Inc., NY, 2010)

11. V.A. Ilyichev. Biosfernaya sovmestimost': Tekhnologii vnedreniya innovatsiy. Goroda, razvivayushchie cheloveka (Librokom, Moscow, 2011)

12. N.G. Miloradova, A.D. Ishkov, Procedia Engineering, 117, 246-251 (2015)

13. Information on http://stud24.ru/construction/analiz-potrebitelej-stroitelnojkompanii/430678-1545143-page3.html

14. Information on http://inec.ru/documents/stroymaterial-rus.pdf

15. R.D. Blackwell, P.W. Miniard, J.F. Engel, Consumer Behavior. 10th Edition (Thomson/South-Western College Pub, 2006)

16. J. Manget, C. Roche, F. Munnich, Capturing the Green Advantage for Consumer Companies (The Boston Consulting Group Year. 2009)

17. L. Hollis, Cities are Good for You. The Genius of the Metropolis (by Bloomsbury Press, New York, 2013)

18. E. Shnyrenkov, I. Pryadko, Procedia Engineering, 117, 325-330 (2015)

19. I.P. Pryadko, International Journal of Applied Engineering Research, 10(21), 4214742152 (2015)

20. Z.I. Ivanova, Strategicheskie prioritety, 3, 28-39 (2014)

21. M. Arsenovic, Z. Radojević, Ž. Jakšić, L. Pezo, Ceramics International, 41(3), 48994905 (2015)

22. M. Arsenovic, Z. Radojević, Ž. Jakšić, L. Pezo, Ceramics International, 41(3), 4890$4898(2015)$

23. J.N. Sheth, B.L. Newman, B.L. Gross, Journal of Business Research, 22, 159-170 (1991)

24. J.N. Sheth, The Journal of marketing, 37(4), 50-56 (1973)

25. Information from: http://reforum.ru/news/v-rossii-sertificirovano-94-zelenyih-zdaniya10569.html 